San Jose State University

SJSU ScholarWorks

June 2013

\title{
The Effect of Water Temperature on Drilling and Ingestion Rates of the Dogwhelk Nucella lapillus Feeding on Mytilus edulis Mussels in the Laboratory
}

Luke P. Miller

Northeastern University, luke.miller@sjsu.edu

Follow this and additional works at: https://scholarworks.sjsu.edu/biol_pub

Part of the Biology Commons

\section{Recommended Citation}

Luke P. Miller. "The Effect of Water Temperature on Drilling and Ingestion Rates of the Dogwhelk Nucella lapillus Feeding on Mytilus edulis Mussels in the Laboratory" Marine Biology (2013): 1489-1496.

This Article is brought to you for free and open access by the Biological Sciences at SJSU ScholarWorks. It has been accepted for inclusion in Faculty Publications, Biological Sciences by an authorized administrator of SJSU ScholarWorks. For more information, please contact scholarworks@sjsu.edu. 
The effect of water temperature on drilling and ingestion rates of the dogwhelk Nucella lapillus feeding on Mytilus edulis mussels in the laboratory

Luke P. Miller*

contact@1ukemiller.org

\section{Abstract}

In highly seasonal intertidal habitats, changes in temperature through the year may drive substantial shifts

11 in feeding and growth rates of organisms. For the dogwhelk Nucella lapillus, attacking and consuming Mytilus

12 edulis mussels can take hours or days, depending on temperature. Handling time of dogwhelks feeding on mussels is

13 therefore greatly affected by ocean temperature. I recorded attack time in the laboratory, partitioned into drilling and

14 consumption time, for juvenile dogwhelks across a range of seawater temperatures representative of field seawater

15 temperatures during the main growing seasons of summer and autumn. The combined length of a drilling attack and

16 subsequent ingestion time tripled across the $10^{\circ} \mathrm{C}$ decline in water temperatures from July through November,

17 driven primarily by an increase in ingestion time. The observed reduction in handling time, coupled with projected 18 sea surface warming in New England by the end of the $21^{\text {st }}$ century, could extend the length of the growing season

19 for Nucella and subsequently have cascading effects on the prey community.

\section{Keywords}

21 Feeding rate; handling time; climate change; sea surface temperature; seasonality; rocky intertidal zone 
Introduction

Foraging for food in the rocky intertidal zone brings a host of potential dangers. Leaving the relative safety

24 of a crevice to forage for a meal can expose animals to predators as well as dangers from the environment, such as

25 wave dislodgement or thermal stress (Denny et al. 2009). For predators feeding on well-defended prey, long

26 handling times can exacerbate the risk posed by the environment and other predators (Pincebourde et al. 2008).

27 Additionally, seasonal temperature changes may drastically impact the rates of physiological processes for

28 ectothermic animals, which can affect both handling time and subsequent digestion rates (Sanford 2002a, b; Yee and

29 Murray 2004). Future climate change, including warming sea surface temperatures, could alter the seasonality of

30 feeding and growth, which will ultimately have cascading effects within the intertidal community (Sanford 2002a;

31 Yamane and Gilman 2009; Gooding et al. 2009).

On the shores of the North Atlantic, the muricid dogwhelk Nucella lapillus feeds on mussels and barnacles

33 (Connell 1961). To gain access to the tissue inside, N. lapillus must typically drill through the exterior shell of the

34 prey before it can insert its proboscis and consume the animal (Rovero et al. 1999a). For dogwhelks feeding on the

35 blue mussel Mytilus edulis, the process of drilling and consuming the mussel may take many hours or days. During

36 this time the dogwhelk must remain relatively stationary on the mussel to complete the attack, potentially leaving

37 the dogwhelk exposed to threats to its own safety (Burrows and Hughes 1989).

The length of an attack by $N$. lapillus on M. edulis is determined by the initial amount of time necessary to gain

entry into the mussel shell, plus the time required to consume the mussel tissue. Dogwhelks that are experienced

40 with feeding on mussels will often learn to quickly gain entry into the mussel shell by inserting the proboscis

41 between the gape of the valves (Rovero et al. 1999a), while young and inexperienced dogwhelks must spend time

42 rasping a hole in the shell with the radula, which takes much longer. The length of this drilling phase may be

43 influenced by a number of factors, primarily where on the mussel shell the dogwhelk chooses to drill and the

44 thickness of the mussel shell in that location. The amount of time needed to consume the mussel tissue after gaining

45 entry can be affected by the relative sizes of predator and prey, the time since last feeding, and environmental

46 influences such as temperature (Hughes and Drewett 1985).

47 Growth rates of N. lapillus during the cold winter and spring seasons are near zero (Largen 1967; Feare 1970).

48 Juvenile $N$. lapillus emerge from egg capsules in the autumn and spend their first winter and spring seasons within 
the safety of crevices (Etter 1989). Warm temperatures in summer are associated with high growth rates in juveniles

50 and rapid consumption rates in adults as well. Body mass of juvenile whelks can increase by $340 \%$ and shell length

51 can double during the summer and early autumn (Etter 1989; Palmer 1990). Feeding rates in adult whelks have been

52 examined in more detail, with warmer temperatures leading to higher consumption rates and reduced digestion time

53 between feeding bouts (Largen 1967; Bayne and Scullard 1978; Burrows and Hughes 1989). These same

54 temperature effects likely exist for juvenile whelks, and the rates of feeding and growth may be particularly

55 important at this life stage, when they determine the time needed to reach reproductive size and reach sizes large

56 enough to be resistant to predation. Although there have been numerous recent studies on the feeding behavior of

57 juvenile dogwhelks in response to predatory crab chemical cues, particularly during the summer growing season

58 (Trussell et al. 2006a; Trussell et al. 2006b; Matassa et al. 2011), the effects of temperature on feeding rates of

59 juvenile dogwhelks has received less attention. Climate models project future increases in sea surface temperature

60 of several degrees through much of the year within the habitat range of N. lapillus (Meehl et al. 2007; IPCC 2007),

61 which could extend the length of the growing season and have cascading effects on energy flow in the intertidal

62 zone.

I tested the hypotheses that 1) changes in ambient water temperature will affect drilling rates and the time

64 required to successfully access mussel tissue, 2) ingestion time following a successful drilling attack will proceed

65 faster at warmer water temperatures, and 3) total handling time from the start of an attack to the completion of

66 ingestion will be shorter in warmer water. I used a hydrophone and time lapse camera to measure the time course of

67 drilling and consumption of M. edulis by juvenile $N$. lapillus dogwhelks in mesocosms during the primary summer

68 growing season and through the decreasing temperatures of autumn. In addition to the hypotheses above, these

69 observations allowed me to assess the effect of the mussel shell thickness on drilling time, the effect of snail size on

70 drilling and ingestion rate, and the effect of mussel size on ingestion rate. Using estimates of increasing sea surface

71 temperatures in the future, I discuss the potential effects of rising temperatures and extended growing seasons for $N$.

72 lapillus.

\section{Materials and methods}

74 Juvenile N. lapillus were collected from Pea Island, adjacent to the Marine Science Center at Nahant, MA

$75\left(42.41554^{\circ} \mathrm{N}, 70.90925^{\circ} \mathrm{W}\right)$ during early June in the summers of 2010 and 2011 . The dogwhelks were held in 
76 plastic containers in seawater tables at the Marine Science Center until they were used in the trials during the

77 subsequent six months. Small M. edulis mussels, collected near Chamberlain, Maine $\left(43.88554^{\circ} \mathrm{N}, 69.47387^{\circ} \mathrm{W}\right)$,

78 were provided ad libitum as food. Prior to use in the experiment, each N. lapillus was starved for five days to

79 standardize hunger levels and to clear the digestive tract so that previous meals would not influence ingestion.

80 Experimental trials were carried out from July to November of 2010 and 2011 (Figure S1). Seawater temperatures in

81 Nahant, MA typically peak at the end of July or during August, and decline through the autumn season. The

82 dogwhelks ranged in size from 11.7 to $14.4 \mathrm{~mm}$ maximum shell length from spire to outer edge of aperture (mean

83 length, $13.2 \mathrm{~mm}$ ), while mussels ranged from 10.3 to $16.8 \mathrm{~mm}$ in length (mean length, $12.9 \mathrm{~mm}$ ). These small

84 Mytilus edulis were representative of the limited range of mussel sizes available on Pea Island where the N. lapillus

85 were originally collected.

Using a piezo-electric hydrophone system similar to that described by Rovero et al. (1999b), I recorded the

87 drilling noise of a dogwhelk attacking a mussel. The hydrophone housing was constructed of acrylic, with the piezo

88 element epoxied directly to the inside of the acrylic housing. The audio cable was connected to a USB microphone

89 pre-amplifier (Griffin iMic, Griffin Technology, Nashville TN, USA), hooked to a computer running a custom

90 LabVIEW program (National Instruments Corporation, Austin, TX, USA) to record the audio stream continuously.

91 For each trial, the right valve of a live M. edulis mussel was glued to the surface of the hydrophone with

92 cyanoacrylate glue. This allowed the mussel to open and close its valves normally, and mussels were frequently

93 observed to extend the foot to secrete byssal threads during the trial. The hydrophone was submerged in a $1.5 \mathrm{~L}$ tank

94 hooked to a flow-through seawater system. A starved N. lapillus was placed in the tank and allowed to attack and

95 consume the mussel. Whelks appeared to crawl normally and explored the confines of the tank and the hydrophone

96 surface when placed in the tank. The water level in the container was always kept full, so there was no tidal cycling

97 in the experiment. Every trial was conducted outside under shade with natural day-night cycles. Water temperature

98 was monitored continuously using a TMP-36 sensor (Analog Devices, Norwood, MA, USA).

99 Snail movement during the same trial was recorded using time-lapse images taken with a USB web camera

100 positioned above the tank. A set of red LEDs provided minimal illumination at night. Images were captured every

101 three minutes by the LabVIEW program. The time lapse images were used to mark the time when a dogwhelk first

102 contacted the mussel, and when the dogwhelk finally departed from the consumed mussel. The time course of the 
103 drilling phase was analyzed using Audacity software (version 1.3beta2010) to visualize each audio recording as a

104 spectrogram where the noise from the discrete rasps of the drilling attack could be seen. The start and end times of

105 each rasping bout, comprised of many discrete rasping noises occurring about two seconds apart, was recorded to

106 the nearest second. Pauses in drilling lasting more than ten seconds marked the end of a rasping bout. The period

107 between individual rasp strokes was sampled at the start, middle, and end of the drilling phase of the attack for each

108 snail. The end of the drilling phase and beginning of the ingestion phase was taken as the point where rasping noise

109 permanently ceased. This transition was accompanied by the snail beginning to shift its shell repeatedly, presumably

110 to allow the proboscis to reach all interior portions of the mussel shell through the drill hole. The end of the

111 ingestion phase was marked as the time when the snail crawled away from the mussel. After the snail departed the

112 mussel, I measured the exterior dimensions of the mussel to the nearest $0.01 \mathrm{~mm}$ using digital calipers, and

113 measured the thickness of the shell immediately surrounding the drill hole to the nearest $0.001 \mathrm{~mm}$ using a digital

114 micrometer. In order to account for the possible influence of the smaller amount of shell material removed when a

115 dogwhelk drilled on the lip of a mussel valve compared to drilling wholly on the valve, I estimated the volume of

116 shell material that made up the drill hole. I measured the area of the drill hole (to the nearest $0.01 \mathrm{~mm}^{2}$ ) using

117 ImageJ software (Rasband, 2013), and multiplied that area by the average thickness around the drill hole to estimate

118 the volume of shell material removed. The maximum shell length of the dogwhelk, from the tip of the spire to the

119 end of the siphonal canal, was measured with calipers to the nearest $0.01 \mathrm{~mm}$. I measured dogwhelk weight by

120 poking the snail to encourage it to retract fully into the shell, wiping away any excess water with a paper towel, and

121 weighing on a balance to the nearest $0.1 \mathrm{mg}$. In every trial, the dogwhelk consumed all of the tissue in the mussel

122 shells, except for occasional remnants of the adductor muscles and small sections of the mantle edge. Each

123 dogwhelk was only used once during these trials.

124 Prior to carrying out multiple regression analyses, I assessed potential collinearity of predictor variables

125 using scatterplots and by calculating variance inflation factors for the available predictors (Fox and Weisberg 2011).

126 Of the available predictors, I removed mussel shell width and height, along with snail mass, due to high collinearity

127 with other predictors. The remaining variables - water temperature, mussel shell length, the volume of shell material

128 removed from the drill hole, and dogwhelk shell length - were used as predictors in the multiple regression models.

129 The response variables in these analyses were drilling time, rasping rate, ingestion time, and total attack length. All

130 analyses were out in R 2.14.1 (R Development Core Team 2012). I fit a series of preliminary models including all 
131 interactions among the predictor variables, and used likelihood ratio tests to examine the potential for interactions.

132 None of the interaction terms were significant, but the small sample size ( $\mathrm{n}=18$ snails) limits the ability to elucidate

133 interactions. Due to the small sample size, I subsequently restricted the set of linear models reported here to additive

134 models without interaction terms to avoid overfitting. For the multiple regression of drilling time, I used water

135 temperature, snail length, and the volume of shell material removed from the drill hole as predictor variables.

136 Mussel length was not included in this model, as it was assumed drill hole size would have a more direct

137 relationship to drilling time. For the analyses of ingestion time and total attack length, mussel shell length was

138 substituted for drill hole volume as a predictor variable, as the time taken to ingest the mussel was likely driven by

139 the amount of tissue available (a function of shell size) rather than the shell thickness that had already been

140 penetrated. In general, it is likely that pairing larger snails with smaller mussels, or vice versa, would result in

141 significant interactions affecting the duration of the different phases of attack discussed here (Hughes and Dunkin

142 1984). The narrow range of snail and mussel sizes used here should help mitigate the potential influence of these

143 interactions within the sample, but extrapolating results to other size classes or temperature ranges should be

144 cautioned against. The distributions of model residuals and quantile-quantile plots were inspected to ensure that the

145 assumption of homogeneity of variances was met. There were no obvious patterns in the residuals, and all analyses

146 were carried out with untransformed variables.

I derived estimates of historical and future whelk feeding rates from a combination of the total attack length

148 regression model (converted to a feeding rate, mussels day ${ }^{-1}$ ) and climate model projections of sea surface

149 temperature. I extracted sea surface temperature projections for grid cells adjacent to the study site from a set of

150 eight atmospheric-ocean global circulation models obtained from the World Climate Research Programme's

151 Coupled Model Intercomparison project (Meehl et al. 2007, Table S1). Modeled monthly average sea surface

152 temperatures were sampled for the last two decades of the $20^{\text {th }}$ century and $21^{\text {st }}$ century, using the SRES A1B

153 emissions scenario results for the $21^{\text {st }}$ century models (IPCC Working Group III 2000). The projected sea surface

154 temperatures were bootstrap resampled to produce a feeding rate estimate for each month separately by first

155 resampling the set of pooled temperatures from the 20 years of estimates of a given month from the eight models.

156 The bootstrapped mean temperature value for each of the 10,000 iterations was used to predict the mean feeding rate

157 and standard deviation from the multiple regression model for that temperature, using the average size of mussels

158 and whelks in the experiment. A final feeding rate for the temperature was then sampled from a random normal 
159 distribution around that mean using the associated standard deviation. The 10,000 estimates of feeding rate for a

160 month were then used to calculate a mean feeding rate and confidence intervals. The bootstrap estimation was

161 carried out separately for each month when historical ocean temperatures in the models were within the bounds of

162 the experimental trial temperatures (May to December).

\section{Results}

164 Out of 44 experimental trials with feeding snails, 18 trials yielded usable data for this study. Data from the

165 other trials had to be excluded for a variety of reasons, typically due to poor sound quality from the hydrophone

166 when dogwhelks drilled the valve of the mussel that was not directly glued to the hydrophone. Of the 18 dogwhelks

167 retained in the data set, 8 drilled on the lip of the mussel valve, leaving a semi-circular hole, while the remaining

168 dogwhelks drilled entirely on the valve, leaving a circular hole.

169 When drilling, dogwhelks made a rasping stroke every $1.9 \mathrm{~s}( \pm 0.56 \mathrm{~s}, 1 \mathrm{SD})$ on average. The rasp stroke

170 period was significantly influenced by water temperature (Figure 1), which ranged from 9.1 to $19.6^{\circ} \mathrm{C}$ during the

171 summer and autumn seasons. Dividing the total length of all rasping bouts by the rasping stroke period for each

172 snail's drilling phase, it took between 568 and 4060 rasps, with an average of 2072 rasps ( $\pm 1036,1 \mathrm{SD})$, to

173 penetrate a mussel shell. The shell thickness around each drill hole ranged from 0.097 to $0.276 \mathrm{~mm}$ (mean thickness,

$1740.183 \mathrm{~mm}$ ), and the volume of shell material removed from drill holes ranged from 0.005 to $0.076 \mathrm{~mm}^{3}$ (mean 0.044

$\left.175 \pm 0.021 \mathrm{~mm}^{3}, 1 \mathrm{SD}\right)$.

The drilling phase of the attack lasted $6.4 \mathrm{hr}$ on average $( \pm 3.9 \mathrm{hr}, 1 \mathrm{SD})$, and ranged from 0.9 to $14.2 \mathrm{hr}$.

177 During the drilling phase, active rasping bouts lasted an average of $4.1 \mathrm{~min}( \pm 2.0 \mathrm{~min}, 1 \mathrm{SD})$. Between active

178 rasping bouts, when the hydrophone did not detect any noise, it is assumed that the snail was dissolving the organic

179 matrix of the mussel shell inside the drill hole using secretions from the accessory boring organ (Rovero et al.

180 1999b). These quiet periods lasted $17.1 \mathrm{~min}( \pm 7.9 \mathrm{~min}, 1 \mathrm{SD})$ on average. The length of the drilling phase was not

181 well predicted by the linear model (Table 1A, Figure 2A). Drilling through a greater volume of shell material tended

182 to increase the length of the drilling phase, though not significantly. 
$1851{ }^{\circ} \mathrm{C}$ reduced the average length of the ingestion phase by $3.6 \mathrm{hr}( \pm 1.7 \mathrm{hr}, 95 \% \mathrm{CI})$ in the regression model.

186 Increasing mussel length by $1 \mathrm{~mm}$, which should increase the mass of tissue available to feed on, increased ingestion

187 time by $6.0 \mathrm{hr}( \pm 2.8 \mathrm{hr}, 95 \% \mathrm{CI})$. Larger snails ingested their prey faster, leading to a reduction of ingestion time by

$188 \quad 8.8 \mathrm{hr}( \pm 6.7 \mathrm{hr}, 95 \% \mathrm{CI})$ for each $1 \mathrm{~mm}$ increase in snail length.

When the drilling phase and ingestion phase lengths were combined to estimate total attack time, water

190 temperature, mussel length, and snail length each remained significant predictors (Table 1C, Figure 2C). Increasing

191 water temperature by $1^{\circ} \mathrm{C}$ reduced the overall length of the attack by $4.1 \mathrm{hr}( \pm 1.9 \mathrm{hr}, 95 \% \mathrm{CI})$, while increasing

192 mussel length by $1 \mathrm{~mm}$ increased the length of the attack by $7.3 \mathrm{hr}( \pm 3.1 \mathrm{hr}, 95 \% \mathrm{CI})$, and increasing snail length by

$1931 \mathrm{~mm}$ reduced the total attack time by $10.1 \mathrm{hr}( \pm 7.4 \mathrm{hr}, 95 \% \mathrm{CI})$.

194 Sea surface temperatures during May through December near the study site are projected to rise $2.8^{\circ} \mathrm{C}$ by

195 the end of the $21^{\text {st }}$ century under the A1B emissions scenario. Rising sea surface temperatures could increase the

196 feeding rates of dogwhelks by $25 \%$ on average, though there is substantial overlap in the historical and future

197 estimates of average monthly feeding rate (Figure 3).

\section{Discussion}

Several factors influence the behavior, feeding rate, and growth rate of $N$. lapillus foraging on rocky shores,

200 which in turn affect their impact on prey species and ultimately, the community composition as a whole. Predatory

201 crabs, wave exposure, desiccation, and heat stress influence when and where $N$. lapillus elects to forage for food

202 (Burrows and Hughes 1989; Vadas et al. 1994; Matassa and Trussell 2011). These limitations on the foraging rates

203 of dogwhelks may be partially offset by the accumulation of experience preying on mussels (Rovero et al. 1999a) or

204 by inherently higher foraging rates of dogwhelks from wave-exposed sites (Menge 1978; Burrows and Hughes

205 1990). The current study highlights the role that seasonal temperature shifts can play in determining dogwhelk

206 feeding rates. Feeding rates peak during the warmest summer temperatures to support the fastest growth, as shown

207 here and in earlier studies (Largen 1967; Bayne and Scullard 1978; Etter 1989; Palmer 1990). As the ocean cools

208 through the autumn, the time needed for ingestion lengthens, more than tripling the total handling time in the span of

209 the $10^{\circ} \mathrm{C}$ seawater temperature decline encompassed in this study $\left(\mathrm{Q}_{10}=3.7\right.$ for feeding rate, mussels day $\left.{ }^{-1}\right)$. 
Over the narrow range of mussel shell thicknesses measured in this study (0.098 to $0.276 \mathrm{~mm}$ ), shell

211 thickness had only a small effect on drilling time. The average drilling rate measured here, $1.03 \pm 0.78 \mathrm{~mm} \mathrm{day}^{-1}(1$

212 SD), was faster than previous estimates for N. lapillus feeding on larger M. edulis (Hughes and Dunkin 1984;

213 Rovero et al. 1999a, 0.36 and $0.29 \mathrm{~mm} \mathrm{day}^{-1}$, respectively). The rasp stroke period (seconds between the start of two 214 rasp strokes) observed here is similar to the value (1.5 s) measured by Rovero et al. (1999b) for rapidly drilling adult 215 whelks ( $35 \mathrm{~mm}$ shell length) at $17^{\circ} \mathrm{C}$, although adult whelks were also often observed to have longer periods of 5 $21610 \mathrm{~s}$ between individual rasp strokes. Due to the large variation in drilling phase length in this study, there is little 217 evidence that drilling through Mytilus shell is affected by water temperature, even though the time between rasp 218 strokes increased significantly at colder water temperatures. A similar change in rasping rate with temperature has 219 been observed in grazing herbivorous gastropods in the field (Petraitis 1992). Drilling through a M. edulis shell 220 involves alternating phases of active rasping and phases of dissolution of the shell by the accessory boring organ 221 secretions (Chétail and Fournié 1969; Carriker 1981). Colder temperatures should slow the rates of chemical 222 reactions causing shell dissolution, although the solubility of $\mathrm{CaCO}_{3}$ structures rises in cold waters (Fabry et al. 223 2008), which could make the drilling process easier. However, the lack of evidence for an increase in drilling phase 224 length with decreasing temperature in these trials may simply be due to behavioral variation in drilling effort 225 between snails masking any temperature effect.

The conditions in these experimental trials represent a low-stress scenario for dogwhelks feeding on 227 mussels. In the field, prey handling times in the range observed here would encompass multiple low tides and 228 potentially expose the dogwhelk to predators, to wave disturbance at high tide, or to desiccation stress at low tide 229 (Hughes and Drewett 1985; Burrows and Hughes 1989; Vadas et al. 1994). Aerial exposure at moderate 230 temperatures may increase respiration rates (Sandison 1967), which comes with an energetic cost. Feeding rates may 231 also increase with moderate aerial exposure (Stickle et al. 1985), though stressful high temperatures tend to depress 232 feeding rates in intertidal gastropods (Brown and Stickle 2002; Yamane and Gilman 2009). N. lapillus foraging 233 rates decrease during extreme high temperatures at low tide and when water temperatures approach $25^{\circ} \mathrm{C}$ (Largen 234 1967; Menge 1978). The peak in future estimated feeding rates shown in Figure 3 in July, August, and September is 235 an extrapolation beyond the temperature range of the feeding experiment, and feeding rates during those months 236 may not increase as much as is shown, due to curtailed feeding rates at peak summer temperatures. However, there 237 may be unexplored physiological capacity for acclimation and effective feeding at seawater temperatures near $25^{\circ} \mathrm{C}$. 
238 While increasing peak summer temperatures may negatively impact foraging by increasing the threat of thermal 239 stress, warming seawater temperatures in the spring, early summer, and fall may prolong the season of high feeding 240 and growth rates (Stickle et al. 1985; Stickle and Bayne 1987), possibly offsetting the effects of reduced feeding 241 during peak summer temperatures. Excluding July, August and September, the increase in future projected feeding 242 rates for May to December shown in Figure 3 ranges from $21 \%$ to $42 \%$ on average, although the $95 \%$ confidence 243 intervals overlap with the historical estimates.

244 This study demonstrates a strong relationship between prey handling time and seawater temperature for

245 juvenile dogwhelks, but predicting the eventual community-level responses to decreasing handling time and 246 increased feeding rates of dogwhelks will require further information. The feeding rates derived here do not include 247 subsequent digestion time that may be required before snails can begin foraging for their next meal (Burrows and 248 Hughes 1991; Stickle et al. 1985), though the time required for digestion has also been shown to decrease in adult 249 dogwhelks at higher temperatures (Bayne and Scullard 1978). Incorporating an estimate of the digestion time 250 between meals would lower the absolute value of the estimated feeding rates shown here, but could enhance the 251 relative increase in feeding rates projected under warming sea surface temperature conditions if snails in warmer 252 waters finish digesting their meals faster than those in cooler waters. This comparison also assumes that search time 253 and encounter rates do not change appreciably in future climates, but these factors might change significantly as the 254 community responds to climate change. Estimating the transfer of energy from lower to higher trophic levels will 255 also require estimates of metabolism and the growth efficiency of dogwhelks across a range of temperatures. Past 256 work with eastern Atlantic adult N. lapillus populations showed highest growth efficiencies at moderate 257 temperatures $\left(10-15^{\circ} \mathrm{C}\right)$, with negative growth efficiencies at low $\left(5^{\circ} \mathrm{C}\right)$ and high $\left(20^{\circ} \mathrm{C}\right)$ temperatures (Stickle and 258 Bayne 1987). Projected warming trends around Nahant, MA could keep winter sea surface temperatures above $5^{\circ} \mathrm{C}$, 259 allowing dogwhelks to forego winter torpor, continue feeding, and grow more than recent historical winter 260 temperatures allowed. But for these same dogwhelks operating in a warming environment in summer, the rate of 261 increase in metabolic costs may outstrip increased feeding rates, as demonstrated in other systems (Rall et al. 2010; 262 Lemoine and Burkepile 2012). Thus, at peak temperatures in summer, the ingestion efficiency (ingestion rate 263 divided by metabolic rate) may decrease until a dogwhelk is burning more calories through metabolic maintenance 264 pathways than it can effectively consume, leading to negative growth rates. Higher feeding rates could increase the 
per capita effect of $N$. lapillus on prey populations of M. edulis, and could negatively affect mussel populations

266 where dogwhelks occur in high densities.

Rising temperatures will not impact dogwhelks in isolation, so the parallel effects of warmer seawater

temperatures on predatory crabs, M. edulis, and other predators and prey resources in the system will shape the

community response. Fisher et al. (2009) found evidence for increasing $N$. lapillus body sizes relative to early $20^{\text {th }}$

century samples, and they present several hypotheses for the increase, including faster growth in warmer waters, increased coastal productivity driving increases in prey abundance and value, and the loss of non-crab predators of

272 dogwhelks. Predatory crab distributions have been shifting in concert with warming trends in the Gulf of Maine, and 273 with the introduction of new species through human activities (Welch 1968; Freeman and Byers 2006). The mussel

274 M. edulis can also thicken its shell in response to predator cues (Freeman and Byers 2006), and warmer climate

275 conditions can decrease M. edulis growth efficiency and bring it closer to its thermal tolerance limits (Widdows and

276 Bayne 1971; Jones et al. 2009). So while the present study provides insight into how changing seawater temperature

277 might affect dogwhelk feeding rates, this represents only one piece of a much larger puzzle composed of the

278 numerous species-specific physiological responses to climate warming and the emergent patterns resulting from the

279 interactions between these species.

\section{Acknowledgements}

The author was supported by a National Science Foundation grant OCE-0727628 to G. C. Trussell. C. M.

Matassa collected the whelks and mussels, M. E. Bracken provided space for the monitoring equipment. C. A.

284 monitoring feeding behavior.

\section{References}

Audacity Development Team (2010) Audacity 1.3beta. http://audacity.sourceforge.net/

Bayne BL, Scullard C (1978) Rates of feeding by Thais (Nucella) lapillus (L.). J Exp Mar Biol Ecol 32:113-129

Brown KM, Stickle WB (2002) Physical constraints on the foraging ecology of a predatory snail. Mar Freshw Behav Physiol 35 (3):157-166

Burrows MT, Hughes RN (1989) Natural foraging of the dogwhelk, Nucella lapillus (Linnaeus) - the weather and whether to feed. J Molluscan Stud 55 (AY):285-295

Burrows MT, Hughes RN (1990) Variation in growth and consumption among individuals and populations of dogwhelks, Nucella lapillus - a link between foraging behavior and fitness. J Anim Ecol 59 (2):723-742 
Burrows MT, Hughes RN (1991) Variation in foraging behavior among individuals and populations of dogwhelks, Nucella lapillus - natural constraints on energy intake. J Anim Ecol 60 (2):497-514

Carriker MR (1981) Shell penetration and feeding by naticacean and muricacean predatory gastropods: a synthesis. Malacologia 20:403-422

Chétail M, Fournié J (1969) Shell-boring mechanism of the gastropod, Purpura (Thais) lapillus: a physiological demonstration of the role of carbonic anhydrase in the dissolution of CaCO3. Am Zool 9 (3):983-990. doi:10.1093/icb/9.3.983

Connell JH (1961) Effects of competition, predation by Thais lapillus, and other factors on natural populations of the barnacle Balanus balanoides. Ecol Monogr 31 (1):61-104

Denny MW, Hunt LJH, Miller LP, Harley CDG (2009) On the prediction of extreme ecological events. Ecol Monogr 79 (3):397-421. doi:10.1890/08-0579.1

Etter RJ (1989) Life history variation in the intertidal snail Nucella lapillus across a wave-exposure gradient. Ecology 70 (6):1857-1876

Fabry VJ, Seibel BA, Feely RA, Orr JC (2008) Impacts of ocean acidification on marine fauna and ecosystem processes. ICES J Mar Sci 65 (3):414-432

Feare CJ (1970) Aspects of the ecology of an exposed shore population of dogwhelks Nucella lapillus (L.). Oecologia 5:1-18

Freeman AS, Byers JE (2006) Divergent induced responses to an invasive predator in marine mussel populations. Science 313:831-833

Fox J, Weisberg S (2011) An R Companion to Applied Regression. 2nd edn. SAGE Publications, Thousand Oaks, CA

Gooding RA, Harley CDG, Tang E (2009) Elevated water temperature and carbon dioxide concentration increase the growth of a keystone echinoderm. Proc Natl Acad Sci USA 106 (23):9316-9321. doi:10.1073/pnas.0811143106

Hughes RN, Drewett D (1985) A comparison of the foraging behavior of dogwhelks, Nucella lapillus (L.), feeding on barnacles or mussels on the shore. J Molluscan Stud 51 (1):73-77

Hughes RN, Dunkin SdB (1984) Behavioural components of prey selection by dogwhelks, Nucella lapillus (L.), feeding on mussels, Mytilus edulis L., in the laboratory. J Exp Mar Biol Ecol 77 (1-2):45-68. doi:10.1016/0022-0981(84)90050-9

IPCC Working Group III (2000) IPCC Special Report Emissions Scenarios. Summary for Policymakers. Intergovernmental Panel on Climate Change. 20 pgs.

IPCC (2007) Climate Change 2007: The Physical Science Basis. Contribution of Working Group I to the Fourth Assessment Report of the Intergovernmental Panel on Climate Change. Solomon, S, Qin D, Manning M, Chen Z, Marquis M, Averyt KB, Tignor M, Miller HL (eds.) Cambridge University Press, Cambridge, United Kingdom

Jones SJ, Mieszkowska N, Wethey DS (2009) Linking thermal tolerances and biogeography: Mytilus edulis (L.) at its southern limit on the east coast of the United States. Biol Bull 217 (1):73

Largen MJ (1967) The influence of water temperature upon the life of the dog-whelk Thais lapillus (Gastropoda: Prosobranchia). J Anim Ecol 36 (1):207-214

Lemoine NP, Burkepile DE (2012) Temperature-induced mismatches between consumption and metabolism reduce consumer fitness. Ecology 93 (11):2483-2489. doi:10.1890/12-0375.1

Matassa CM, Trussell GC (2011) Landscape of fear influences the relative importance of consumptive and nonconsumptive predator effects. Ecology 92 (12):2258-2266. doi:10.1890/11-0424.1

Meehl GA, Covey C, Delworth TL, Latif M, McAvaney B, Mitchell JFB, Stouffer RJ, Taylor KE (2007) The WCRP CMIP3 multimodel dataset. B Am Meteorol Soc 88:1383-1394. doi:10.1175/BAMS-88-9-1383

Menge BA (1978) Predation intensity in a rocky intertidal community. Effect of an algal canopy, wave action, and desiccation on predator feeding rates. Oecologia 34 (4):17-35

Palmer AR (1990) Effect of crab effluent and scent of damaged conspecifics on feeding, growth, and shell morphology of the Atlantic dogwhelk Nucella lapillus (L.). Hydrobiologia 193:155-182

Petraitis, PS (1992). Effects of body size and water temperature on grazing rates of four intertidal gastropods. Aust $J$ Ecology 17(4): 409-414

Pincebourde S, Sanford E, Helmuth B (2008) Body temperature during low tide alters the feeding performance of a top intertidal predator. Limnol Oceanogr 53 (4):1562-1573

R Development Core Team (2012) R: A language and environment for statistical computing. R Foundation for Statistical Computing, Vienna, Austria http://www.R-project.org/ 
Rall BC, Vucic-Pestic O, Ehnes RB, Emmerson M, Brose U (2010) Temperature, predator-prey interaction strength and population stability. Glob Change Biol 16 (8):2145-2157. doi:10.1111/j.1365-2486.2009.02124.x http://rsb.info.nih.gov/ij/

Rovero F, Hughes RN, Chelazzi G (1999a) Effect of experience on predatory behaviour of dogwhelks. Anim Behav 57:1241-1249

Rovero F, Hughes RN, Chelazzi G (1999b) Automatic recording of the radular activity of dogwhelks (Nucella lapillus) drilling mussels (Mytilus edulis). J Mar Biol Assoc U K 79 (6):1079-1083. doi:10.1017/S0025315499001320

Sandison EE (1967) Respiratory response to temperature and temperature tolerance of some intertidal gastropods. J Exp Mar Biol Ecol 1:271-281

Sanford E (2002a) The feeding, growth, and energetics of two rocky intertidal predators (Pisaster ochraceus and Nucella canaliculata) under water temperatures simulating episodic upwelling. J Exp Mar Biol Ecol 273:199-218. doi:10.1016/S0022-0981(02)00164-8

Sanford E (2002b) Water temperature, predation, and the neglected role of physiological rate effects in rocky intertidal communities. Integr Comp Biol 42:881-891

Stickle WB, Bayne BL (1987) Energetics of the muricid gastropod Thais (Nucella) lapillus (L.). J Exp Mar Biol Ecol 107 (3):263-278. doi:10.1016/0022-0981(87)90043-8

Stickle WB, Moore MN, Bayne BL (1985) Effects of temperature, salinity and aerial exposure on predation and lysosomal stability of the dogwhelk Thais (Nucella) lapillus (L.). J Exp Mar Biol Ecol 93 (3):235-258. doi:10.1016/0022-0981(85)90242-41

Trussell, G.C., P.J. Ewanchuk and C.M. Matassa (2006). Habitat effects on the relative importance of trait- and density-mediated indirect interactions. Ecol Lett 9(11): 1245-1252

Trussell, G.C., P.J. Ewanchuk and C.M. Matassa (2006). The fear of being eaten reduces energy transfer in a simple food chain. Ecology 87(12): 2979-2984

Vadas RL, Burrows MT, Hughes RN (1994) Foraging strategies of dogwhelks, Nucella lapillus (L.): interacting effects of age, diet and chemical cues to the threat of predation. Oecologia 100 (4):439-450. doi:10.1007/bf00317866

Widdows J, Bayne BL (1971) Temperature acclimation of Mytilus edulis with reference to its energy budget. J Mar Biol Assoc U K 51:827-843

Yamane L, Gilman SE (2009) Opposite responses by an intertidal predator to increasing aquatic and aerial temperatures. Mar Ecol Prog Ser 393:27-36. doi:10.3354/meps08276

Yee EH, Murray SN (2004) Effects of temperature on activity, food consumption rates, and gut passage times of seaweed-eating Tegula species (Trochidae) from California. Mar Biol 145:895-903. doi:10.1007/s00227004-1379-6 
Tables

388 Table 1. Coefficient estimates for multiple regression models of A) drilling time, B) ingestion time, and C) total

389 attack time (drilling and ingestion time combined). Bold values represent significant partial regression slopes. Shell

390 lengths were measured in $\mathrm{mm}$.

\begin{tabular}{|c|c|c|c|c|}
\hline A. & $\begin{array}{l}\text { Drilling Time, } \mathrm{hr} \\
\text { Coefficients }\end{array}$ & Estimate & Std. Error & $p$ \\
\hline & Intercept & -13.90 & 23.01 & 0.555 \\
\hline & Water temperature & -0.094 & 0.389 & 0.813 \\
\hline & Drill hole volume $\left(\mathrm{mm}^{3}\right)$ & 91.35 & 59.40 & 0.146 \\
\hline & Snail length & 1.373 & 1.386 & 0.339 \\
\hline & $F_{(3,14)}=1.33, p=0.305, \mathrm{a}$ & $R^{2}=0.05$ & & \\
\hline
\end{tabular}

B. Ingestion Time, hr

\begin{tabular}{lccc}
\multicolumn{1}{c}{ Coefficients } & Estimate & Std. Error & $p$ \\
\hline Intercept & 119.04 & 38.91 & $\mathbf{0 . 0 0 8 5}$ \\
Water temperature & -3.648 & 0.782 & $\mathbf{0 . 0 0 0 3}$ \\
Mussel length & 6.045 & 1.328 & $\mathbf{0 . 0 0 0 5}$ \\
Snail length & -8.791 & 3.125 & $\mathbf{0 . 0 1 3 8}$
\end{tabular}

$F_{(3,14)}=16.73, p=<\mathbf{0 . 0 0 0 1}$, adjusted $R^{2}=0.74$

\begin{tabular}{lccc}
\hline C. Total Attack Time, hr & & & \\
\multicolumn{1}{c}{ Coefficients } & Estimate & Std. Error & $p$ \\
\hline Intercept & 132.5 & 43.33 & $\mathbf{0 . 0 0 8 5}$ \\
Water temperature & -4.083 & 0.895 & $\mathbf{0 . 0 0 0 4}$ \\
Mussel length & 7.312 & 1.460 & $\mathbf{0 . 0 0 0 2}$ \\
Snail length & -10.05 & 3.438 & $\mathbf{0 . 0 1 1 1}$
\end{tabular}

$F_{(3,14)}=17.78, p=\left\langle\mathbf{0 . 0 0 0 1}\right.$, adjusted $R^{2}=0.75$ 


\section{$392 \quad$ Figure legends}

393 Fig. 1 Rasping stroke period (seconds per stroke) vs. water temperature. Dashed lines represent 95\% confidence 394 intervals.

395 Fig. 2 Marginal effects plots showing fitted partial regressions for A) drilling time, B) ingestion time, and C) total 396 attack time (drilling and ingestion combined) against each predictor variable, when each of the other predictors was

397 held at its mean value. The rug of points along the borders represents the distribution of the original data points used 398 to fit the linear models. Dashed lines represent 95\% confidence limits. Coefficient estimates are given in Table 2.

399 Fig. 3 Bootstrapped estimates of $N$. lapillus feeding rates (mussels day ${ }^{-1}$ ) under current and future projected sea 400 surface temperatures. The secondary ordinate axis shows corresponding sea surface temperature estimates from the 401 model ensemble for the ocean grid cell closest to Nahant, Massachusetts. The thick and thin error bars represent $40250 \%$ and $95 \%$ confidence intervals, respectively. The gray background regions represent temperature conditions 403 outside of the range of observed temperatures on which the feeding rate regression model was based.

\section{Supplemental figure legend}

406 Fig S1. Seawater temperatures at the Marine Science Center, Nahant, MA, USA during 2010 and 2011 (upper and 407 lower panels, respectively). Gray bars represent the timing of the feeding trials included in this data set. 


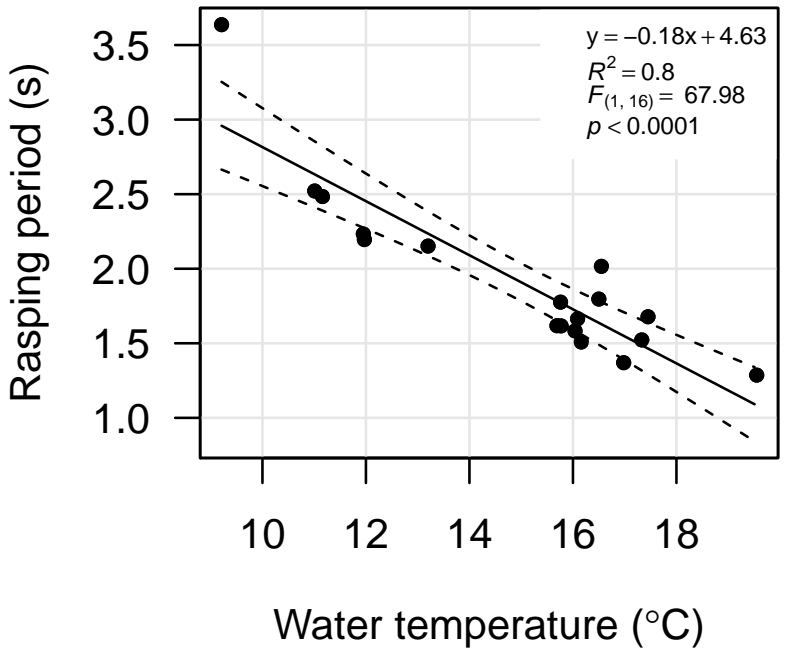




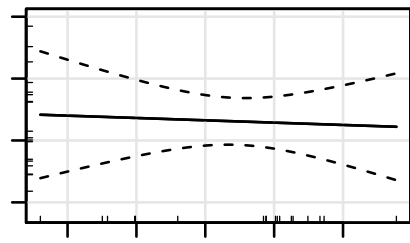

$\begin{array}{lllll}10 & 12 & 14 & 16 & 18\end{array}$

Water temperature $\left({ }^{\circ} \mathrm{C}\right)$

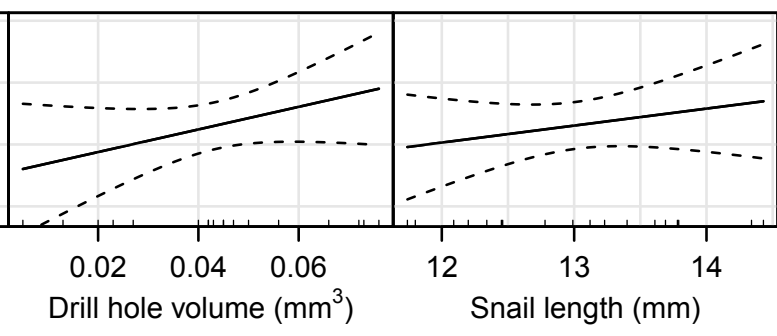

B)

है

$\mathrm{C}$

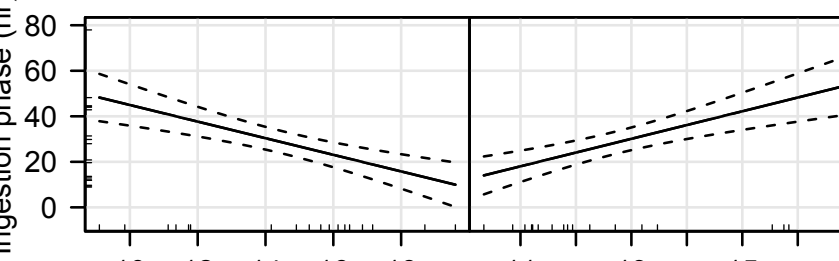

$\begin{array}{lllll}10 & 12 & 14 & 16 & 18\end{array}$

$11 \quad 13$

15

Mussel length (mm)

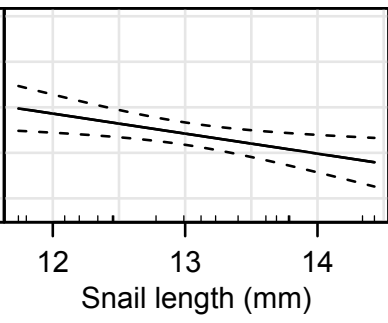

ב
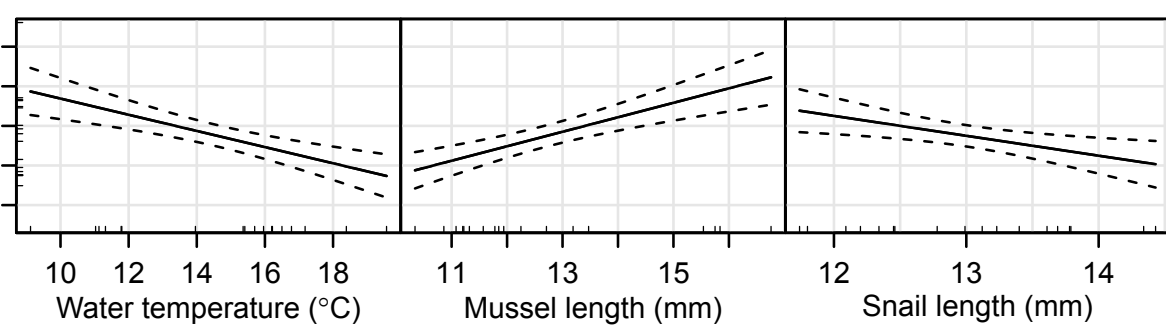


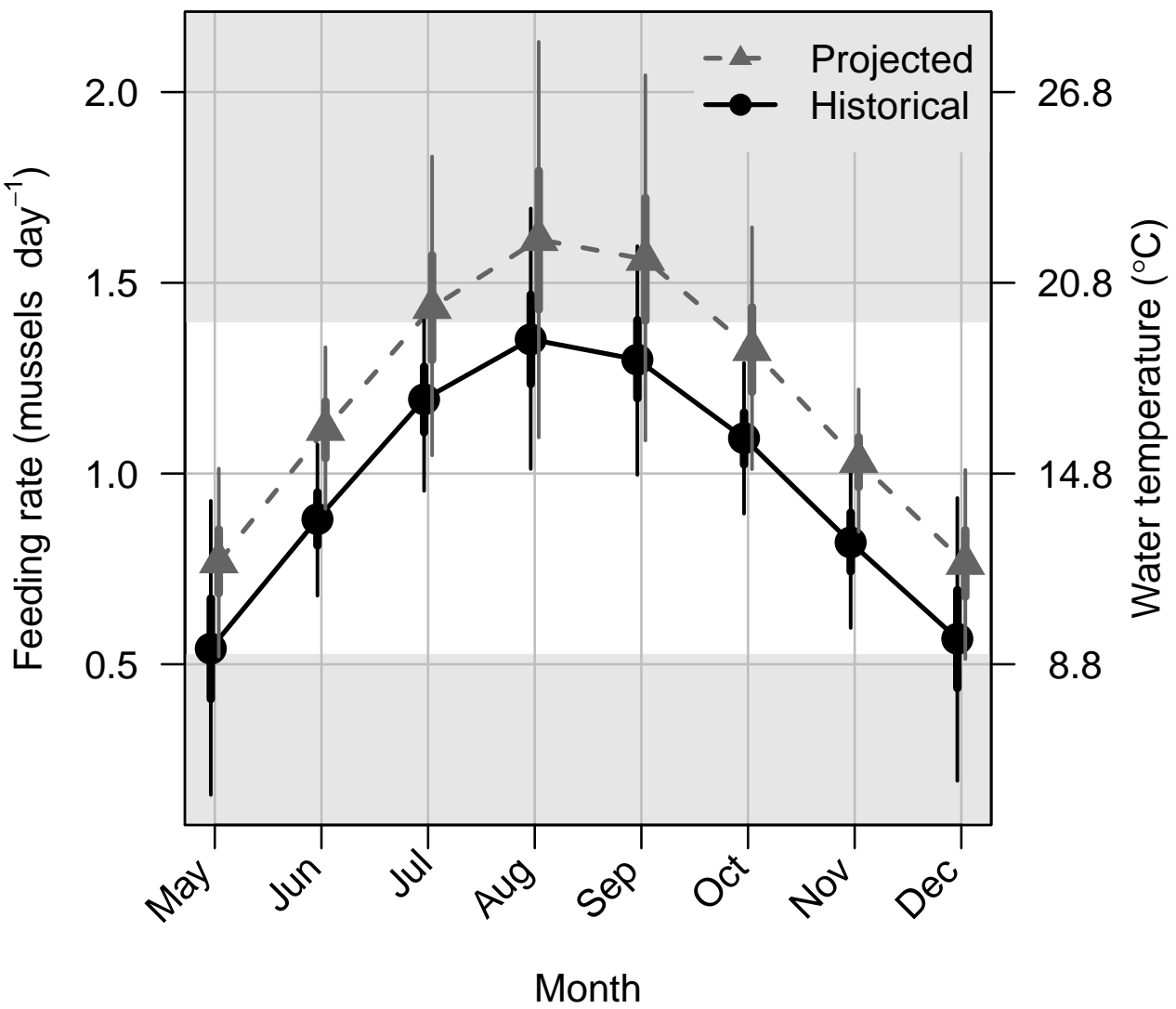


